\title{
Loss of life estimation - Review, developments and challenges
}

\author{
S.N. (Bas) Jonkman ${ }^{1, a}$, B. (Bob) Maaskant ${ }^{2}$, B. (Bas) Kolen ${ }^{1,2}$ and J.T. (Jason) Needham ${ }^{3}$ \\ ${ }^{1}$ Delft University of Technology, Stevinweg 1, 2628 CN, Delft, the Netherlands \\ ${ }^{2}$ HKV Consultants, PO Box 2120, 8203 AC, Lelystad, the Netherlands \\ ${ }^{3}$ USACE Risk Management Center, 609 Second Street, Davis, CA, United States
}

\begin{abstract}
This paper presents an overview and review of methods developed for loss of life estimation in flood risk assessment. These methods range from empirical to simulation based approaches that are used to support flood risk analyses and emergency management. Similarities and differences between the modelling approaches, input and output types and applications are discussed. Challenges to the field are summarized, including empirical data collection for validation and benchmarking and comparison studies.
\end{abstract}

\section{Introduction and background}

Loss of life is one of the most important consequences of flood disasters. Historical events, such as the 1953 flooding in the Netherlands (1853 fatalities) and the flooding of New Orleans due to hurricane Katrina (more than 1000 fatalities), have demonstrated that the magnitude of life loss can be significant. Various methods have been developed in the Netherlands, US and other countries for various fields of application such as levee failure, dam breaching, and tsunamis. Life loss estimates have been used for various purposes, including the evaluation of flood risks in the Netherlands, dam safety in the US and Canada, and emergency planning in various countries.

Over the past decade there has been significant developments in the field of loss of life estimation, and several groups have developed models for a better characterization of life loss - see section 2 and (Jonkman et al., 2008) for an overview. Whereas the first methods were mainly based on general empirical information and variables (e.g. water depth or warning time), during the last decade more complex simulation based approaches have been developed. Although these methods provide first insights in the range of loss of life that could be expected, there are still a lot of questions related to the empirical foundation of these methods and their application for policy decisions. This paper presents a review and systematic analysis of approaches for loss of life estimation. The scope of this paper is limited to statistical and quantitative models. For example, multicriteria semi-qualitative models are not considered (see e.g. Tapsel et al., 2008). The models in this paper focus on coastal and inland flooding, but tsunamis are not explicity considered. As life loss estimation also requires insight in evacuation effectiveness, evacuation modelling

\footnotetext{
${ }^{a}$ Corresponding author: $\underline{\text { S.N.Jonkman@tudelft.nl }}$
}

approaches are also included within the scope of the paper.

This paper is structured as follows. Section 2 contains a review of approaches for life loss estimation. Section 3 presents the main challenges to the field.

\section{Overview of methods for life loss estimation}

\subsection{General}

Estimation of the loss of life requires insight in a number of variables and elements that can be clarified based on the formula below (Jonkman, 2007):

$N=F_{d}\left(1-F_{E}\right) N_{P A R}$

Where:

$\mathrm{N}$ - loss of life estimate; $\mathrm{F}_{\mathrm{d}}-$ mortality fraction; $\mathrm{F}_{\mathrm{E}}-$ evacuation fraction (also evacuation effectiveness), $\mathrm{N}_{\mathrm{PAR}}$ - number of people at risk.

Thus, analysis of life loss requires insight in three main factors. Firstly, there is the number of people potentially at risk $\left(\mathrm{N}_{\mathrm{PAR}}\right)$, which can be derived from population densities and sometimes data that distinguishes presence of people as a function of the time of the day or season. Secondly, the effectiveness of the preventive evacuation and the shelter strategies need to be defined to determine the number of people that will be exposed to the flood. This can be done by various approaches, including traffic models at different levels of detail (See Kolen, 2013 for an overview). An accurate estimate for the evacuation effectiveness fraction $\left(\mathrm{F}_{\mathrm{E}}\right)$ is 
essential. For example, note that changing the value of $\mathrm{F}_{\mathrm{E}}$ from 0.95 to 0.9 will double the life loss estimate. Thirdly, there is the estimation of the mortality fraction $F_{d}$. It is the ratio between the number of people killed and the number of people exposed in the floodzone,

The mortality is generally expressed as a function of flood characteristics, such as depth, flow velocity and rise rate, and outputs of hydrodynamic flood simulations are generally used to estimate these parameters. In some models, mortality is also related to structural building performance in flood loads or is made dependent on the state in which people are present (e.g. in a building, car or in the water by foot).

\subsection{Overview of loss of life models}

Models for life loss estimation can be used for different purposes, such as the support of policy and engineering design decisions that are related to (acceptable) flood risk and to provide information to planners and emergency managers to improve and optimize their strategies. Examples of loss of life models are the empirical method developed for storm surge flooding in the Netherlands (Jonkman, 2007) and the flood risks to people approach developed in the UK (Penning Rowsell et al., 2005); statistical simulation models such as HEC-FIA; and agent based models, such as BC Hydro's LSM and USACE's LifeSim, that give a detailed simulation of flooding and people movement and behaviour. More comprehensive overviews and discussions of the various methods are included in (Jonkman, 2007; Jonkman et al., 2008, di Mauro et al., 2012).

A general characterization of various models is shown in Figure 1 with respect to their level of detail and modeling principles. The level of detail (vertical axis) varies from the modeling of each individual's fatality rate to an overall estimate for the whole event. On the horizontal axis the basic modeling principles are categorized. Mechanistic models are those that model the individual behaviour and the causes of death. Empirical models relate mortality in the exposed population to event characteristics.

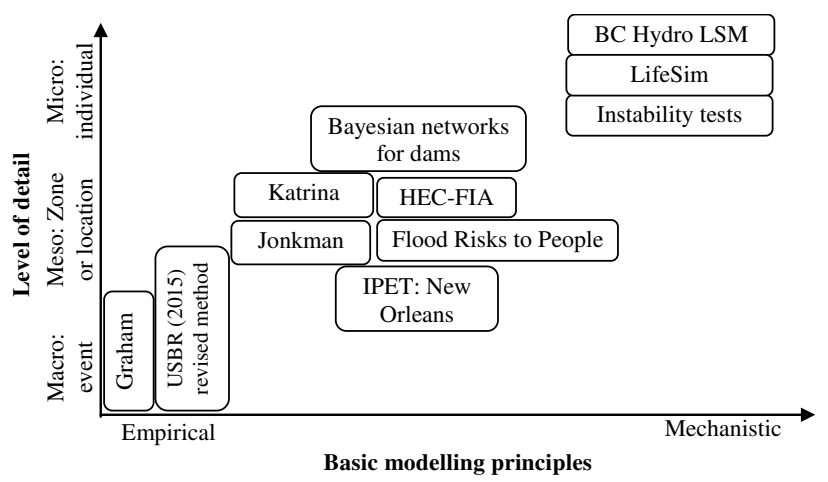

Figure 1. General characterization of various models.

In appendix A, a more extensive comparison between the different models is presented. The table shows the differences in field of application, type of model and mortality functions, evacuation concept/model and the differences in input variables (depth, velocity, rise rate, warning time).

For the field of application there are two type of events, levee breaching and dam failures. For both type of events specific models have been developed, based on empirical methods, examples are 1953, Katrina and USBR. Models that are applicable to both type of events, and any other source of flooding, are based on dynamic methods, this method simulates the individual event, examples are LifeSim and LSM.

The functions used to estimate the mortality can be divided into three types:

- Stepwise; this type of functions divides the flooded area in different zones based on flood characteristics and uses one mortality per zone to determine the loss of life.

- Continuous; in this type of functions the flooded area can also be divided in different zones but within each zone the mortality rate is dependent on the flood characteristics within that zone.

- Simulation; This is the most detailed method and describes the specific event and simulates the location of people at risk and the development of the flood characteristics over time.

Depending on the type of problem and available input data, a choice for a model type can be made. For example, for a first quick estimate the empirical and macro scale models may be suitable. Simulation models can be used to verify findings from empirical assessments prior to major investments based on those findings as well as informing the decision-making process for selecting measures to reduce potential loss of life (e.g. improved warning or evacuation planning, shelter in place options, etc.)

In addition to life loss modeling, a crucial step in the assessment is often the analysis of evacuation effectiveness. The different type of evacuation models is described in paragraph 2.3.

\subsection{Overview evacuation models}

Evacuation is defined as the process of alerting, warning, deciding, preparing, departing and (temporarily) removing people, animals, personal belongings and corporate stock and supplies from an unsafe location. The effectiveness of evacuation can be defined with evacuation models. These models describe the (expected) number of people that can move to a defined location within a window of time for a scenario of evacuation. The results of these model can be combined with flood scenarios to estimate economic damage and loss of life. Different types of models can be defined, such as deterministic and probabilistic models.

Deterministic models are models in which scenarios for evacuation can be defined. A scenario for evacuation describes the logistic progress and the number of people that reach the intended destination over time based on a 
set of chosen boundary conditions and a defined road networks. For each scenario, the model is based on a set of assumptions, such as the population that evacuates, the capacity and routes of the infrastructure, and the decisions of the authorities (strategy measures), first responders and the public (when and how to evacuate). These models can further be divided into three types (Petruccelli 2003; Mens 2008):

- Dissipation rate models, they use an aggregate state formula to estimate the evacuation time based on the size of an area and its population density. These models are also called macro models. An example is the "Evacuation Calculator" as described in (van Zuilekom et al. 2005; Barendregt et al. 2002) or the "strategy builder" (Kolen 2013).

- Manual capacity models, they use techniques to allocate the population on the (road) network while taking the road capacity into account. These models are also called 'meso' or 'macro dynamic' models. An example is "Dynamic traffic Module" as described by (van Zuilekom et al. 2005; Barendregt et al. 2002) or "EVAQ" by (Pel et al. 2008). A model which takes preventive and vertical evacuation into account which is used in the US is HEC-FIA (USACE 2011) and a model developed for The Netherlands is defined by (Pleijter et al 2015).

- Micro simulation models, these models simulate the evacuation process on the network at a micro (individual) level. Each individual receptor is modeled, and there is a detailed description of the road network. An example is the "Life Safety Model" by (BC Hydro 2006) and LifeSim as applied in the US (McClelland and Bowles 1999)

Probabilistic models are models in which the expected value of evacuation can be defined. An example of a probabilistic model is EvacuAid (Kolen et al 2013), which uses a databases of scenario's and the probabilities of these events. In this model the probability of each event is based on the statistics of the underlying parameters which can be influenced by several measures.

The added value of each model depends on the decision problem and available time for calculations. Because of the calculation time, a dissipation rate model has most value to obtain an understanding about the effectiveness of evacuation and to assess the impact of uncertainties and the effectiveness of measures. Manual Capacity models can be used to do research about how the traffic spreads over the network over time and how local bottle necks can be optimized. Micro simulation require more detailed information, but provide a better understanding of how the evacuating population interacts with the flood waters, including potential for loss of life during the evacuation process, and how different measures can help improve the evacuation process and reduce loss of life.

\section{Challenges}

\subsection{Empirical data collection}

A general issue in loss of life and evacuation modeling is the lack of historical calibration data. The required amount and level of detail of calibration and validation data depends on the type of model. Relatively simple empirical models only require a limited number of "fields" (e.g. water depth, population at risk and life loss data). More complex models with a lot of model parameters also require more information for a proper validation.

There are some important datasets. For example, the New Orleans / Katrina loss of life dataset (Jonkman et al., 2009) could be highly relevant for such a comparison. Another recent event with significant life loss was the flooding on the West coast of France due to storm Xynthia in the year 2010 (Vinet et al., 2012). This led to about 40 fatalities due to surge and flood effects. A recent validation effort (di Mauro and de Bruijn, 2012) focused on the Canvey Island case study. This island was flooded during the 1953 surge on the North Sea and about 60 fatalities occurred on the island. It could further investigated how important factors that are currently not included in the life models, e.g. water temperature, could be incorporated.

In a recent effort, as part of the development of the updated empirical method of the US Bureau of Reclamation, a number of case histories were analysed to strengthen the data basis. Table 1 gives an overview of some of these events and the variables analysed. A particular number of Chinese dam failures were added to the collection due to the collaboration with Chinese experts (see e.g. figure 2). Challenges in the analysis of historical cases concern the reliability and accuracy of information.

\begin{tabular}{|c|c|c|c|c|}
\hline Location & Date & Type & $\begin{array}{c}\text { Life } \\
\text { loss }\end{array}$ & Variables \\
\hline $\begin{array}{c}\text { Changkai } \\
\text { levee, Fuzhou } \\
\text { China }\end{array}$ & $21 / 6 / 2010$ & $\begin{array}{c}\text { Levee } \\
\text { breach }\end{array}$ & 0 & $\begin{array}{c}\mathrm{D}, \mathrm{v}, \\
\text { evacuation }\end{array}$ \\
\hline $\begin{array}{c}\text { Banqiao dam, } \\
\text { China }\end{array}$ & $8 / 8 / 1975$ & $\begin{array}{c}\text { Dam } \\
\text { failure }\end{array}$ & 827 & $\mathrm{Dv}$, \\
\hline $\begin{array}{c}\text { Situ gintung, } \\
\text { Jakarta, } \\
\text { Indonesia }\end{array}$ & $27 / 3 / 2009$ & $\begin{array}{c}\text { Dam } \\
\text { failure }\end{array}$ & 100 & $\begin{array}{c}\mathrm{D}, \mathrm{v}, \\
\text { warning }\end{array}$ \\
\hline
\end{tabular}

Table 1. Examples of events for which information was collected as part of the development of USBR's new empirical method (Jonkman, 2013a) 


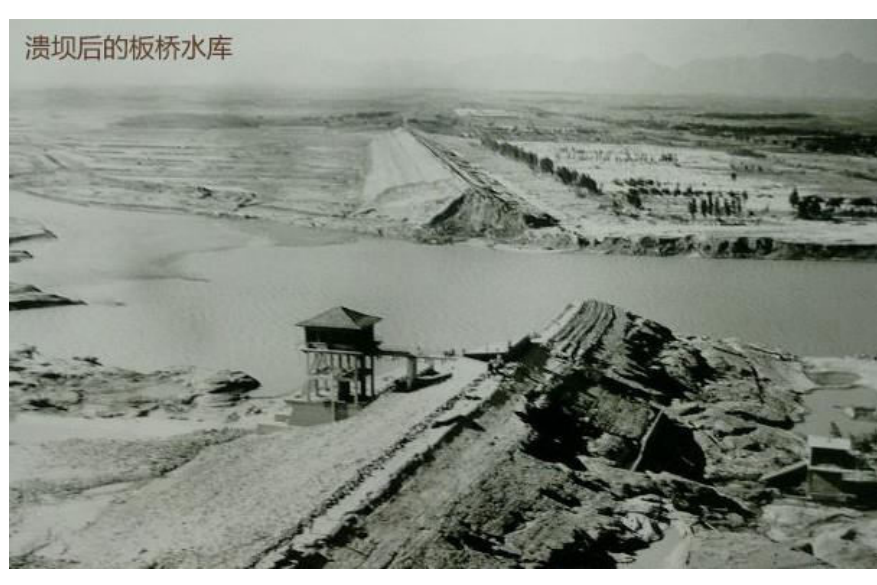

Figure 2 The breached Banqiao dam in 1975.

\subsection{Experimental research on model components}

Several loss of life models use criteria to assess the stability of people in flowing water and criteria for the destruction of buildings. These are typically expressed by means of the depth-velocity or $\mathrm{dv}$ product $[\mathrm{m} 2 / \mathrm{s}]$. Examples, are the criteria based on experimental research with test persons (Abt et al., 1989; Jonkman and Penning Rowsell, 2008) or for buildings (Clausen, 1989).

Especially for buildings, these criteria are highly dependent on the type of building and foundation. Also, other impacts, such as debris could play a role. Also, for some "states" included in the life loss models, only limited empirical information is available. Particularly for cars that are evacuating / driving in flowing waters, there is limited knowledge of what adequate thresholds for instability are (Smith et al., 2015). For these cases and states, further testing could be very useful to extend the empirical model basis.

\subsection{Improving estimates of evacuation effectiveness}

The effectiveness of an evacuation can be described by four elements (Gwynne 2002, Kolen 2013):

1. Threat and impact including the lead time and size of the (in this case flood) event

2. Citizens' response

3. Decisions made by the authorities

4. Environment and traffic infrastructure (demographics, infrastructure, buildings, capacity of emergency services).

When forecasts become clearer and uncertainties of forecasts decline, people and decision makers begin to act over time. Authorities can increase the effectiveness of an evacuation by offering clear, concise, and complete information about the threat, adapting the physical environment, and using symbols to influence behaviour and stimulate specific citizen responses. The autonomous response of citizens can create an overload or inefficient use of the road capacity, the available equipment and limitations for authorities to implement further mitigating measures. Several models describe the possible response of citizens in the case of a natural hazard based on the interaction between environmental processes, social processes and individual processes (Lindell and Perry 1992; Grothmann and Reusswig 2006; Sorensen 2000).

In the case of evacuation due to flooding, it is known that not all people will act directly after receiving the warning, as it takes time after a warning before people will begin to evacuate (Lindell et al. 2002). Because floods do not respect administrative boundaries, multiple decision makers are involved. The autonomous response of people and the impact of the involved decision makers can result in counterproductive measures as well as less optimal use of the available resources and infrastructure.

The most effective measures depends on actual (given the event) and local circumstances. The available time can be divided over: $\mathrm{t}$

- The warning time, which can be divided in the Delay Time (time between detection and issue of a warning), Diffusion Time (time between issuing a warning and receiving a warning) and Protective Action (time between receiving a warning and action) (Mileti \& Sorensen, 2015)

- Travel time as the time needed for going from place A to B using the road network.

- Arrival time as the time needed to arrive at the final destination after leaving the road network.

When the road network is not fully used more effort can be put in the warning time. However, when too many people participate at the same time related to the road capacity (as is the case of The Netherlands), the effectives of road use can decline because more congestion can occur (Pel 2011). Therefore, the message has to be defined carefully and to be considered as operational measures to influence effectiveness of evacuation.

Authorities can also influence evacuation by requirements to design road infrastructure, shelters or emergency services, however in case of a threat these cannot be influenced any more.

\subsection{Benchmarking and comparison studies}

A comparison study between different type of loss of life models, 1953, Katrina, HEC-FIA, LifeSim (Jonkman 2013b) shows that application of the methods on the same case can lead to a wide range of outcomes.

The 1953 functions are sensitive to rise rates and the HEC-FIA and LifeSim models are sensitive to flood depths. In figure 3 the mortality rates are show for one flood scenario in the Natomas basin (Jonkman, 2013b).

In this scenario rise rates are an important factor in the northern part of the basin, this explains the outcome of the 1953 mortality rates. In the southern part the rise rates are lower but the flood depths are relatively large, 
this explains the high mortality rates given by the how the traffic will spread over the network can be used to HEC-FIA method. The Katrina function gives a more define optimistic or pessimistic scenarios which can be used gradual increase of the mortality rates depending on the as a bandwidth for the results. In case of a great bandwidth flood depth, this leads to a more smooth mortality rate additional measures can be considered.

over the basin.

Further research on the comparison between the different methods by applying them on the same cases will increase the understanding of the different methods and will lead to a better use of the models. In addition, applying the different models on historic cases can strengthen the validity of the models by showing how well they predict the event.
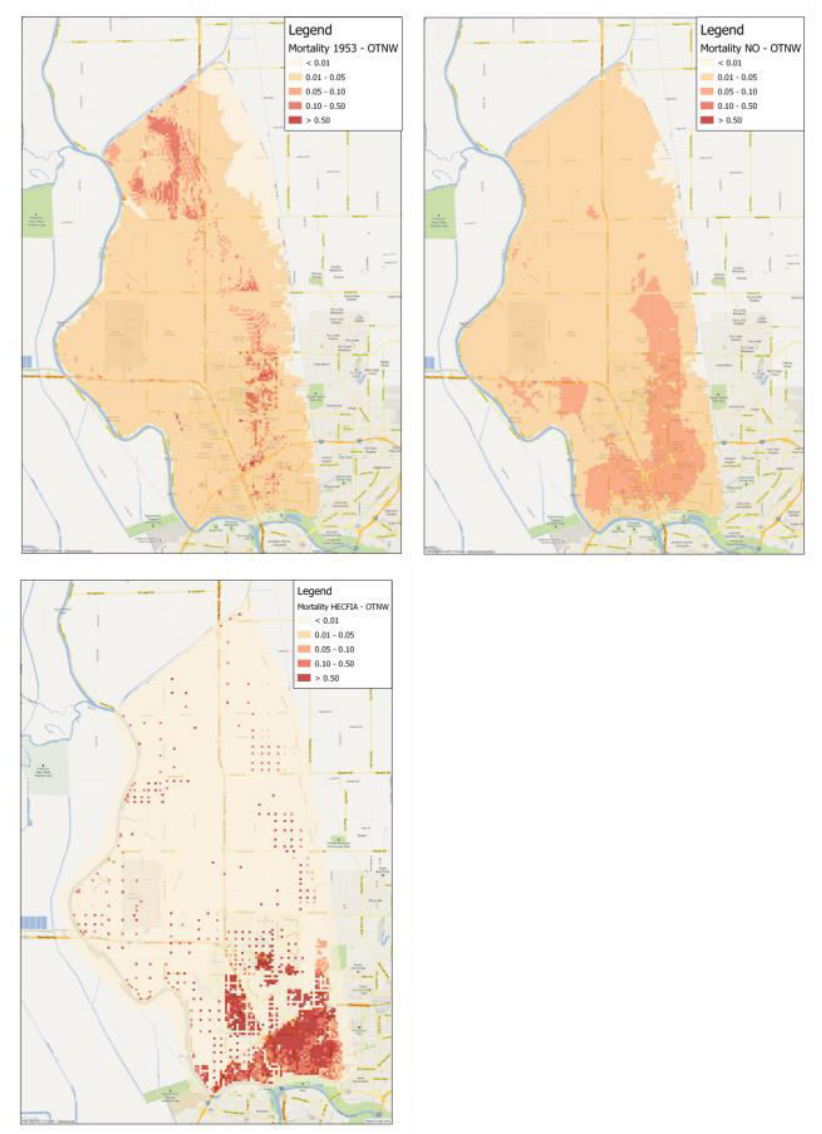

Figure 3 Mortality rates for case Natomas Basin (Upper left 1953, upper right Katrina, lower left HEC-FIA) (Jonkman, 2013b).

\subsection{Evacuation modelling}

Evacuation models can be used to estimate the effectiveness of evacuation. However each model has to be used taking into account the uncertainties. Validation of evacuation models is, in most cases, not possible because data for mass evacuations are limited (Pel 2011). Even when evacuations are frequent, such as once in five to ten years, the lessons learned will be implemented afterwards. Other variables included are the uncertainty in the threat and (citizens') response during a subsequent event (Kolen 2013). Despite the problems with validation of the results, knowledge about the conditions of the parameters in the model and the algorithms used regarding

\section{Concluding remarks}

The field of loss of life modelling has shown significant development over the last decade. The first loss of life models were mainly relatively simple empirical relationships. Several new modelling approaches have been developed over the last decade. Empirical data from recent (e.g. Katrina) and more historical (e.g. 1953) events has been used to strengthen the empirical model basis. Simulation based models have provided new capabilities to simulate evacuation behaviour and individual "fates".

Many of these models have been used in discussions concerning tolerable risk levels and the need for risk reduction interventions. In the Netherlands, the new capabilities to estimate risk to life have even been a basis for the development of new standards for flood defences, which are based on risk to life. Therefore, these new models have increased insights in flood risk and consequence levels, and have triggered new discussions. For example, the effectiveness of evacuation policies becomes a part of the risk. Accountability issues of governments and agencies with responsibility for warning and evacuation are introduced in discussions on actual and desired risk levels, and the involvement of more actors in flood risk management.

\section{References}

Abt S.R., Wittler R.J., Taylor A., Love D.J. (1989) Human stability in a high flood hazard zone, Water Resources Bulletin Vol. 25 No.4, pp. 881-890

A. Barendregt, J.M. van Noortwijk, M.F.A.M. van Maarseveen, S.I.A. Tutert, M.H.P. Zuidgeest and K.M. van Zuilekom. (2002) Evacuation in case of possible flood (in Dutch). HKV lijn in water and University of Twente.

Clausen, L.K. (1989) Potential Dam Failure: Estimation of Consequences, and Implications for Planning. Unpublished M.Phil. thesis at the School of Geography and Planning at Middlesex Polytechnic collaborating with Binnie and Partners, Redhill.

BC Hydro. (2006) BC Hydro Life safety modelling environment $\mathrm{V} 2.0$ beta User manual.

di Mauro M, de Bruijn K.M., Meloni M. (2012) Quantitative methods for estimating flood fatalities: towards the introduction of loss-of-life estimation in the assessment of flood risk. Natural Hazards, Vol. 63, 1083 - 1113.

Fiedler W., Osmun D., Engemoen W., Feinberg B. (2014) Reclamations' new life loss estimation methodology. Paper presented at the $34^{\text {th }}$ annual USSD conference, San Francisco 2014.

T. Grothmann and F. Reusswig. (2006) People at risk of flooding: why some residents take precautionary action while others do not. Natural Hazards, Vol. 38, pp 101-120.

Graham, WJ (1999) A procedure for estimating loss of life caused by dam failure. Dam safety office report DSO-99-6 
Gwynne S., Galea, E.R., Owen, M., Lawrence, P.J. (2002). An investigation of the aspects of occupant behaviour required for evacuation modeling. Edited by P.R. DeCicco. Vol. 2, Evacuation from fires. New York: Baywood Publishing Company, Inc., Amityville.

IPET (Interagency Performance Evaluation Task Force) (2007) Performance evaluation of the New Orleans and Southeast Louisiana hurricane protection system-volume VII: the consequences, Final report 26 March 2007

Kolen, B. (2013) Certainty of uncertainty in evacuation for threat driven responses, Principles of adaptive evacuation management for flood risk planning in the Netherlands. PhD Thesis University of Nijmegen.

Johnstone W.M., Sakamoto D., Assaf H., Bourban S. (2005) Architecture, Modelling framework and validation of BC Hydro's Virtual Reality Life Safety Model, in: Vrijling et al. (eds.) Proceedings of the International Symposium on Stochastic Hydraulics, May 23, 24 2005, Nijmegen, the Netherlands

Jonkman S.N., Penning-Rowsell E. (2008) Human instability in flood flows, Journal of the American Water Resources Association (JAWRA) Vol. 44 No. 4 August 1008, pp. 1-11

Jonkman S.N. (2007) Loss of life estimation in flood risk assessment. Theory and applications. PhD thesis Delft University (354 pag.)

Jonkman S.N., Hiel L.A., Bea R.G., Foster H., Tsioulou A., Arroyo P., Stallard T., Harris L. (2012) Integrated Risk Assessment for the Natomas Basin (CA) Analysis of Loss of Life and Emergency Management for Floods. ASCE Natural Hazards Review, Vol. 13/4 (November 2012), pp. 297 - 309.

Jonkman S.N., Maaskant B., Kolen B., Zethof M., Lehman W. (2013b) Loss of life, evacuation and emergency management - comparison and application to case studies in the USA. Final draft Research Report Delft University of Technology.

Jonkman S.N., Vrijling J.K., Vrouwenvelder A.C.W.M. (2008) Methods for the estimation of loss of life due to floods: A literature review and a proposal for a new method, Natural Hazards, Vol.46/3, pp. 353-389

Jonkman S.N. (2013a) Review of case histories. Working document

B. Kolen, M. Kok, I. Helsloot and B. Maaskant. (2012) EvacuAid: a probabilistic evacuation model to determine the expected loss of life for different mass evacuation strategies. Risk Analysis doi: 10.1111/j.15396924.2012.01932.x.

M.K. Lindell and R. Perry. (1992) Behavioural Foundations of Community Emergency Planning. Washington DC:

Hemisphere.

M.K. Lindell, C.S. Prater, R.W. Perry and J.Y. Wu. (2002) EMBLEM: an empirically based large-scale evacuation time estimate model: Hazard reduction \& recovery center Texas A\&M University.

McClelland D.M., Bowles D.S. (1999) Life-loss estimation: what can we learn from case histories. In:Proc. of the Australian Committee on Large Dams (ANCOLD) Annual Meeting, Jindabyne, New South Wales, Australia.

Mileti DS. Sorensen JH. (2015) A Guide to Public Alerts and Warnings for Dam and Levee Emergencies. USACE

Mens M.J.P., M. van der Vat and D. Lumbroso. (2008) A comparison of evacuation models for flood event management: Application on the Schelde and Thames estuaries. In Flood Risk Management: Research and practice, edited by 2009 Samuels et al (eds.). London: Taylor \& Francis Group.

A.J. Pel, M.C.J. Bliemer and S.P. Hoogendoorn. (2008). EVAQ: A New Analytical Model for Voluntary and Mandatory Evacuation Strategies on Time-varying Networks. In Proceedings of the 11th International IEEE Conference on Intelligent Transportation Systems. Beijing, China.

A.J. Pel. (2011) Transportation modelling for regional evacuations, Delft University of technology.

M. Peng • L. M. Zhang (2012) Analysis of human risks due to dam-break floods - part 1: a new model based on Bayesian networks Nat Hazards (2012) 64:903-933

G. Pleijter, B. Kolen, S.N. Jonkman, A. Bouwman. (2015) Slimmer evacueren door overstromingen. Magazine Nationale Veiligheid en Crisisbeheersing. P55-56.

Penning-Rowsell E., Floyd P., Ramsbottom D., Surendran S. (2005) Estimating injury and loss of life in floods: A deterministic framework, Natural Hazards Vol. 36 No. 1-2 pp. 43-64

Petruccelli U. (2003) Urban evacuation in seismic emergency conditions. ITE Journal; 73(8):25-30.

G. Smith and D. McLuckie (2015) Delineating hazardous flood conditions to people and property. In : Proc. Of FMA conference, Brisbane Australia. http://www.floodplainconference.com/papers2015/Grantly \%20Smith\%20Full\%20Paper.pdf

J.H. Sorensen. (2000) Hazard warning systems: review of 20 years of progress. Natural hazard reviewed 1:119-125.

Tapsell, S.M. and Tunstall, S.M. (2008) '"I wish I'd never heard of Banbury": the relationship between 'place' and the health impacts of flooding'. Health \& Place (forthcoming June 2008) Vol. 14 (2), 133-154.

USACE (2011a) HEC-FIA, Flood Impact Analysis Software, Draft certification report, November 2011

K.M. van Zuilekom, M.F.A.M. van Maarseveen and M.R. van der Doef. (2005) A Decision Support System for preventive evacuation of people. Geo-information for disaster management, edited by P. Zlatanova Van Oosterom, S. Fendel, E. M. : Springer Berlin Heidelberg.

Vinet F., Lumbroso D., Defossez S., Boissier L. (2012) A comparative analysis of the loss of life during two recent floods in France: the sea surge caused by the storm Xynthia and the flash flood in Var. Natural Hazards April 2012, Vol. 61/3, pp 1179-1201 
Appendix A: Life loss methods

\begin{tabular}{|c|c|c|c|c|c|c|}
\hline Method & $\begin{array}{l}\text { Field of } \\
\text { application }\end{array}$ & $\begin{array}{l}\text { Type of model } \\
\text { and mortality } \\
\text { functions }\end{array}$ & $\begin{array}{l}\text { Evacuation } \\
\text { concept / } \\
\text { model } \\
\end{array}$ & Data basis & variables & Source \\
\hline 1953 & $\begin{array}{l}\text { Levee } \\
\text { breaches, } \\
\text { coastal and } \\
\text { river floods }\end{array}$ & $\begin{array}{l}\text { Empirical; } \\
\text { continuous } \\
\text { function }\end{array}$ & $\begin{array}{l}\text { Evacuation } \\
\text { before flooding } \\
\text { by means of } \\
\text { fraction }\end{array}$ & $\begin{array}{l}1953 \text { flood } \\
\text { disaster in the } \\
\text { UK and } \\
\text { Netherlands }\end{array}$ & $\mathrm{d}, \mathrm{v}, \mathrm{w}$ & $\begin{array}{l}\text { Jonkman et al. } \\
\text { (2008); } \\
\text { Jonkman, } 2007\end{array}$ \\
\hline Katrina & $\begin{array}{l}\text { Levee } \\
\text { breaches, } \\
\text { coastal and } \\
\text { river floods }\end{array}$ & $\begin{array}{l}\text { Empirical; } \\
\text { continuous } \\
\text { function }\end{array}$ & Same & $\begin{array}{l}\text { Hurricane } \\
\text { Katrina }\end{array}$ & $\begin{array}{l}\mathrm{d}, \mathrm{v}, \text { evacuation } \\
\text { fraction }\end{array}$ & $\begin{array}{l}\text { Jonkman et al. } \\
\text { (2009); }\end{array}$ \\
\hline HEC FIA & $\begin{array}{l}\text { Levee and } \\
\text { dam breaches, } \\
\text { coastal and } \\
\text { river floods }\end{array}$ & $\begin{array}{l}\text { Empirical; step } \\
\text { wise function }\end{array}$ & $\begin{array}{l}\text { Includes } \\
\text { warning and } \\
\text { evacuation } \\
\text { routine before } \\
\text { and during a } \\
\text { flood. }\end{array}$ & $\begin{array}{l}\text { Derived from } \\
\text { Lifesim }\end{array}$ & $\begin{array}{l}\mathrm{D}, \mathrm{v}, \mathrm{t}, \text { building } \\
\text { collapse }\end{array}$ & USACE, 2011 \\
\hline $\begin{array}{l}\text { IPET - New } \\
\text { Orleans - } \\
\text { specific } \\
\text { version of } \\
\text { HEC FIA }\end{array}$ & $\begin{array}{l}\text { Levee } \\
\text { breaches } \\
\text { (New } \\
\text { Orleans) }\end{array}$ & $\begin{array}{l}\text { Empirical; step } \\
\text { wise function }\end{array}$ & $\begin{array}{l}\text { Shelter and } \\
\text { warning } \\
\text { included }\end{array}$ & $\begin{array}{l}\text { Hurricane } \\
\text { Katrina }\end{array}$ & $\begin{array}{l}\text { D, shelter } \\
\text { factor, warning, } \\
\text { age }\end{array}$ & IPET (2007) \\
\hline LifeSim & $\begin{array}{l}\text { Levee and } \\
\text { dam breaches, } \\
\text { coastal and } \\
\text { river floods }\end{array}$ & $\begin{array}{l}\text { Dynamic, } \\
\text { simulation }\end{array}$ & $\begin{array}{l}\text { Includes } \\
\text { warning and } \\
\text { evacuation } \\
\text { routine, incl. } \\
\text { road network } \\
\text { before and } \\
\text { during a flood }\end{array}$ & $\begin{array}{l}\text { Various dam } \\
\text { break \& flood } \\
\text { cases }\end{array}$ & $\begin{array}{l}\mathrm{D}, \mathrm{v}, \mathrm{t}, \text { building } \\
\text { collapse }\end{array}$ & $\begin{array}{l}\text { McClelland } \\
\text { and Bowles, } \\
\text { 1999, 2002; } \\
\text { Aboelata, 2003 }\end{array}$ \\
\hline $\begin{array}{l}\text { Graham } \\
\text { (former } \\
\text { USBR } \\
\text { method) }\end{array}$ & Dam failures & $\begin{array}{l}\text { Empirical } \\
\text { stepwise }\end{array}$ & $\begin{array}{l}\text { No direct } \\
\text { evacuation, } \\
\text { warning factor } \\
\text { included }\end{array}$ & $\begin{array}{l}\text { Various dam } \\
\text { break \& flood } \\
\text { cases }\end{array}$ & $\begin{array}{l}\text { Severity } \\
\text { classification } \\
\text { based on d, v } \\
\text { and warning } \\
\text { time }\end{array}$ & Graham (1999) \\
\hline $\begin{array}{l}\text { USBR } \\
(2015)- \\
\text { revised } \\
\text { empirical } \\
\text { method }\end{array}$ & Dam failures & $\begin{array}{l}\text { Empirical; } \\
\text { continuous } \\
\text { function }\end{array}$ & $\begin{array}{l}\text { No direct } \\
\text { evacuation, } \\
\text { differentiation } \\
\text { of warning (no, } \\
\text { little, adequate) }\end{array}$ & $\begin{array}{l}\text { Dam failures, } \\
\text { case histories } \\
\text { - based on } \\
\text { Graham } \\
\text { (1999) but } \\
\text { revised and } \\
\text { updated }\end{array}$ & $\mathrm{D}, \mathrm{v}$, warning & $\begin{array}{l}\text { Fiedler et al. } \\
(2014)\end{array}$ \\
\hline $\begin{array}{l}\text { Bayesian } \\
\text { networks for } \\
\text { dams }\end{array}$ & Dam failures & $\begin{array}{l}\text { Empirical, } \\
\text { Bayesian } \\
\text { network (i.e. } \\
\text { probabilistic } \\
\text { relationships) }\end{array}$ & $\begin{array}{l}\text { Evacuation, } \\
\text { shelter and } \\
\text { warning } \\
\text { included as } \\
\text { factors }\end{array}$ & $\begin{array}{l}\text { Dam failure, } \\
343 \text { case } \\
\text { histories }\end{array}$ & $\mathrm{D}, \mathrm{v}, \mathrm{t}$, distance & $\begin{array}{l}\text { Peng and } \\
\text { Zhang (2012) }\end{array}$ \\
\hline LSM & $\begin{array}{l}\text { Dam failures } \\
\text { and levee } \\
\text { breaches }\end{array}$ & $\begin{array}{l}\text { Dynamic, } \\
\text { simulation }\end{array}$ & $\begin{array}{l}\text { Warning and } \\
\text { evacuation } \\
\text { included } \\
\text { through micro } \\
\text { simulation }\end{array}$ & $\begin{array}{l}\text { Validation } \\
\text { based on } \\
\text { Malpasset } \\
\text { dam breach }\end{array}$ & $\begin{array}{l}\mathrm{D}, \mathrm{v}, \mathrm{t}, \mathrm{w}, \\
\text { building } \\
\text { collapse }\end{array}$ & $\begin{array}{l}\text { BC Hydro } \\
2006\end{array}$ \\
\hline $\begin{array}{l}\text { Flood Risks } \\
\text { to People }\end{array}$ & $\begin{array}{l}\text { River and } \\
\text { coastal } \\
\text { floods (UK) }\end{array}$ & $\begin{array}{l}\text { Empirical; } \\
\text { ranking }\end{array}$ & - & $\begin{array}{l}\text { Stability tests } \\
\text { and } \\
\text { expert } \\
\text { judgement }\end{array}$ & $\mathrm{D}, \mathrm{v}, \mathrm{w}, \mathrm{t}$ & $\begin{array}{l}\text { Ramsbottom et } \\
\text { al. } \\
(2003,2004)\end{array}$ \\
\hline
\end{tabular}

$* \mathrm{~d}$ - flood depth, $\mathrm{v}$ - flow velocity; $\mathrm{w}$ - rise rate; $\mathrm{t}$ - arrival time 